Dep. of Bacteriology,

Animal Health Research Institute,

Mansoura Laboratory.

\title{
STUDIES ON SOME BACTERIAL CAUSES ASSOCIATED WITH OEDEMATOUS SKIN DISEASE IN BUFFALOES IN DAKAHLIA GOVERNORATE
}

(With 5 Tables)

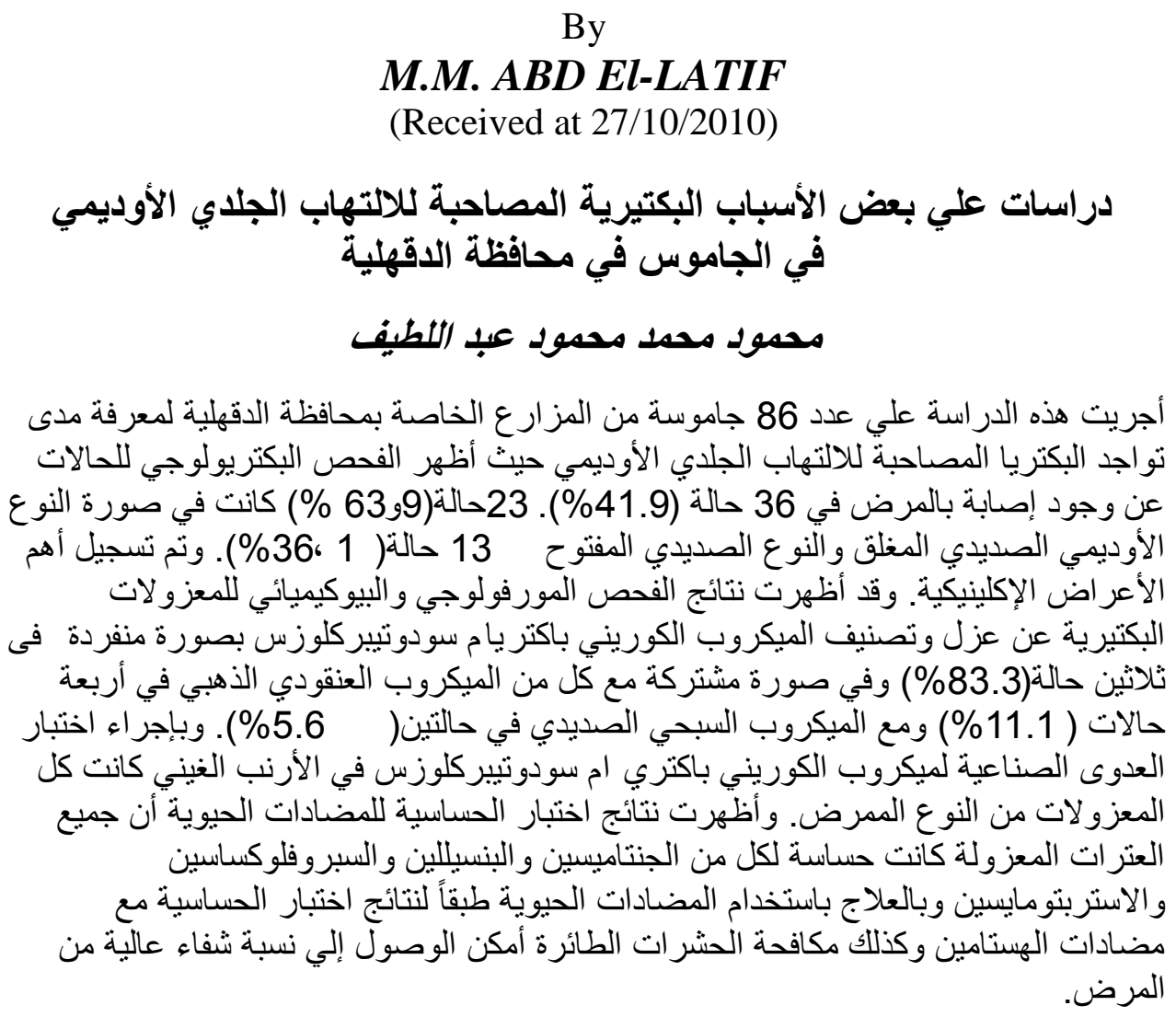

\section{SUMMARY}

This study was carried out on 86 buffaloes from a private farms at Dakahlia Governorate to investigate the bacterial causes associated with oedematous skin disease. Bacteriological examination of the samples revealed that 36 cases $(41.9 \%)$ were positive. 23 cases $(63.9 \%)$ were in form of the closed lesions and 13 cases $(36.1 \%)$ were open lesions. The main clinical signs of the infected buffaloes had been described. Isolated bacteria were subjected for morphological and biochemical identification. The results obtained 
revealed that 30 isolates $(83.3 \%)$ were Corynebacterium pseudotuberculosis in single infection and mixed infection with both Staph. aureus 4 isolates (11.1\%) and Strept. pyogenes 2 isolates (5.6\%). Pathogenicity test for $C$. pseudotuberculosis in guinea pigs indicated that all isolates were pathogenic and cause the death of inoculated animals. Results of antibiogram indicated that most of the isolates were highly sensitive to Gentamycin, Pencillin, Ciprofloxacin and Streptomycin. Treatment by effective antibiotics, antihistaminic and eradication of the flies achieved the recovery from the disease.

Key words: Oedematous skin disease, Bacterial causes, buffaloes, antibiogram.

\section{INTRODUCTION}

Buffaloes may be considered the principles sector of livestock in Egypt. They represent the main source for meat and milk production. This sector had been exposed to different infectious diseases with great economic impact. One of the most serious and specific infectious diseases is the so called oedematous skin disease (OSD) which becomes an endemic disease in Egypt (Selim, 2001). The disease was characterized by low mortality and high morbidity (Khalil et al., 1995) and clinically by hot painful inflammatory swelling that appeared at different areas of the skin and the lymph vessels draining the inflammed area appeared as cord, also swollen local lymph node. The condition of diseased animals was fair with little change in appetite, decreased milk yield and slight rise in body temperature (Al-Gaabary and Ammar, 1999; Pandey et al., 2007; Fontaire and Baird, 2008). The disease has a prolonged course and is highly expensive for treatment (Abd El-Hakeim 2005; Sayed et al., 2007). Several investigations in different Governorate which established that the etiological agent was Corynbacterium pseudotuberculosis as alone or in mixed infection with other pathogen as Staphylococcus spp. and Streptococcus spp. (Barakat et al., 1984; Mostafa, 1984; Ali and Zaitoun 1999; Ghoneim et al., 2001; Sayed et al., 2007; Abd El-Ghafar, 2009). C.pseudotuberculosis serotype II is the main cause of OSD and exotoxin phospholipase D and its lipid contents of the cell wall are the major cause of pathogensis (Selim, 2001). Several authors suggested that the route of transmission of OSD is through the mechanical way only either by contamination of external environment (soil and water) with C.pseudotuberculosis or by external parasites (Hippobosca equina). (Barakat et al., 1984; Khalil et al., 1995; Sayed et al., 2007).

The aim of this study was planned to investigate the prevalence of oedematous skin disease in buffaloes beside identifation of the causative 
pathogens. In addition to detect the pathogenicity and antibiogram for the most isolated bacteria.

\section{MATERIALS and METHODS}

\section{Animals:}

A total number of 86 buffaloes aged from 6 months up to 7 years from a private farms in Dakahlia Governorate during summer season, were investigated in this study. Diseased buffaloes were suffering from skin lesions either closed or opened in the form of diffuse oedematous swelling in different parts of the skin, ulceration and nodular lesions, were also present.

\section{Bacteriological samples:}

A total number of 86 samples were collected from diseased buffaloes by aspiration from closed lesions by sterile syringes after disinfecting the surface using 5\% tincture iodine. A sterile disposable syringe filled with $5 \mathrm{ml}$ sterile saline solution was injected and the contents of the lesion were aspirated with the same syringe. Samples from open lesions were taken by sterile cotton swabs. All samples were taken under complete aseptic conditions and transported as rapidly as possible in ice bag container to the laboratory where isolation and identification of the organisms were performed. Both aspirated exudates and cotton swabs were inoculated into Nutrient broth media overnight and incubated aerobically at $37^{\circ} \mathrm{C}$, then streaked onto $10 \%$ sheep blood agar, Nutrient agar and MacConkey's agar plates and incubated at $37^{\circ} \mathrm{C}$ for 48 hours aerobically. Growing colonies were purified and identified morphologically by Gram's stain (Bailey and Scott's, 1990) and biochemically for glucose, sucrose and maltose fermentation, catalase activity, gelatine liquefaction, urea production, methyl red and nitrate reduction were adopted according to Koneman et al. (1992)

Biotyping of $C$. pseudotuberculosis:

C. pseudotuberculosis was biotyped according to the presence or absence of nitrate reductase enzyme. Biotype I did not express the enzyme (nitrate reduction test negative) whereas biotype II was capable of producing the enzyme (nitrate reduction test positive) (Quinn et al., 2002).

\section{Pathogenicity test :}

Eight guinea pigs of about 250- 350 gm body weight were used in the reisolation of $C$. pseudotuberculosis (The most causative agent of OSD) as well as determination of its pathogenicity. Six guinea pigs were inoculated subcutaneously with isolated C.pseudotuberculosis at dose of $0.25 \mathrm{ml}$ ( $1 \mathrm{ml}$ containing $2 \times 10^{6} \mathrm{CFU}$ ) according to Ibrahim et al. (2007). At 
the same time two guinea pigs (as control) were inoculated with sterile broth by using the same dose and route of inoculation. From dead guinea pigs showed post mortem chanages and reisolation of inoculated isolates according to El- Far (1976) and Rafequ and Mahmoud (2007).

\section{In-vitro antimicrobial susceptibility testing:}

Antibiogram sensitivity was performed for isolated strains by the agar diffusion technique Quinn et al. (2002). The used chemotherapeutic discs were Pencillin (10 1U), Streptomycin $(10 \mu \mathrm{g})$, Gentamycin $(10 \mu \mathrm{g})$, Oxytetracycline $(30 \mu \mathrm{g})$, Ampicillin $(10 \mu \mathrm{g})$, Amoxycillin $(25 \mu \mathrm{g})$, Ciprofloxacin $(20 \mu \mathrm{g})$ and Enrofloxacin $(5 \mu \mathrm{g})$. The degree of sensitivity was determined and interpreted according to Koneman et al. (1992).

\section{RESULTS}

\section{A- Clinical signs :}

The main clinical signs in buffaloes included acute oedematous swellings accompanied with single or multiple abscesses or ulcerative lesions. The lesions were present on the flanks, shoulders, neck, one or more limbs, dewlap and contained either a sero-sanguineous exudates or blood stained yellowish or greenish pus.

\section{B- Results of bacteriological examination :}

The obtained bacteriological results were tabulated in tables (1 -5).

Table 1: Bacteriological examination of the affected buffaloes.

\begin{tabular}{|c|c|c|c|c|c|}
\hline \multirow{2}{*}{ Case of animal } & \multicolumn{2}{|c|}{$\begin{array}{c}\text { Number of } \\
\text { examined buffaloes }\end{array}$} & \multicolumn{2}{|c|}{$\begin{array}{c}\text { Positive } \\
\text { samples }\end{array}$} & \multicolumn{2}{|c|}{$\begin{array}{c}\text { Negative } \\
\text { samples }\end{array}$} \\
\cline { 3 - 6 } & & No. & $\%$ & No. & $\%$ \\
\hline $\begin{array}{l}\text { Affected buffaloes with closed } \\
\text { and open lesions. }\end{array}$ & 86 & 36 & 41.9 & 50 & 58.1 \\
\hline
\end{tabular}

Table 2: Biochemical activities of C. pseudotuberculosis strains isolated from OSD buffaloes.

\begin{tabular}{|c|c|c|c|c|c|c|c|c|}
\hline $\begin{array}{c}\text { Biochemical } \\
\text { activities }\end{array}$ & 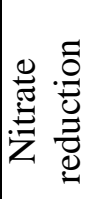 & $\frac{\ddot{E}}{\frac{\tilde{E}}{\tilde{J}}}$ & 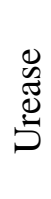 & $\begin{array}{l}\mathscr{D} \\
\stackrel{0}{0} \\
\frac{0}{0} \\
0\end{array}$ & 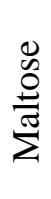 & 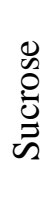 & : & 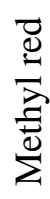 \\
\hline C.pseudotuberculosis & + & + & + & + & + & - & - & + \\
\hline
\end{tabular}


Table 3: Bacterial species isolated from skin lesions of OSD.

\begin{tabular}{|c|c|c|c|c|c|c|}
\hline \multirow{2}{*}{ Bacterial species } & \multicolumn{4}{|c|}{ Forms of the positive OSD buffaloes (36) } & \multicolumn{3}{|c|}{ Total } \\
\cline { 2 - 7 } & \multicolumn{2}{|c|}{ Closed Lesions (23) } & Open lesions (13) & \multicolumn{2}{|c|}{} \\
\cline { 2 - 7 } & No. & $\%$ & No. & $\%$ & No. & $\%$ \\
\hline C. pseudotuberculosis & 23 & 100.0 & 7 & 53.8 & 30 & 83.3 \\
\hline $\begin{array}{c}\text { C. pseudotuberculosis } \\
\text { + Staph. aureus }\end{array}$ & 0 & 0.0 & 4 & 30.8 & 4 & 11.1 \\
\hline $\begin{array}{c}\text { C. pseudotuberculosis } \\
\text { +Strept. Pyogenes }\end{array}$ & 0 & 0.0 & 2 & 15.4 & 2 & 5.6 \\
\hline
\end{tabular}

Table 4: Pathogenicity of C. pseudotuberculosis isolated from OSD infected buffaloes:

\begin{tabular}{|c|c|c|c|c|c|c|c|c|c|}
\hline \multirow{2}{*}{ Inoculated isolate } & \multicolumn{6}{|c|}{ No. of dead guinea pigs/day } & \multicolumn{3}{c|}{ Total } \\
\cline { 2 - 12 } & 1 & 2 & 3 & 4 & 5 & 6 & 7 & No. & $\% *$ \\
\hline C. pseudotuberculosis & 0 & 1 & 2 & 2 & 1 & 0 & 0 & $6 / 6$ & $100 \%$ \\
\hline Control guinea pigs & 6 & 6 & 6 & 6 & 6 & 6 & 6 & 6 & $100 \%$ \\
\hline
\end{tabular}

No. : Number of dead guinea pigs

* : The percent was calculated according to the total number of inoculate guinea pigs

Table 5: Antimicrobial susceptibility testing of bacterial isolates recovered from OSD infected buffaloes

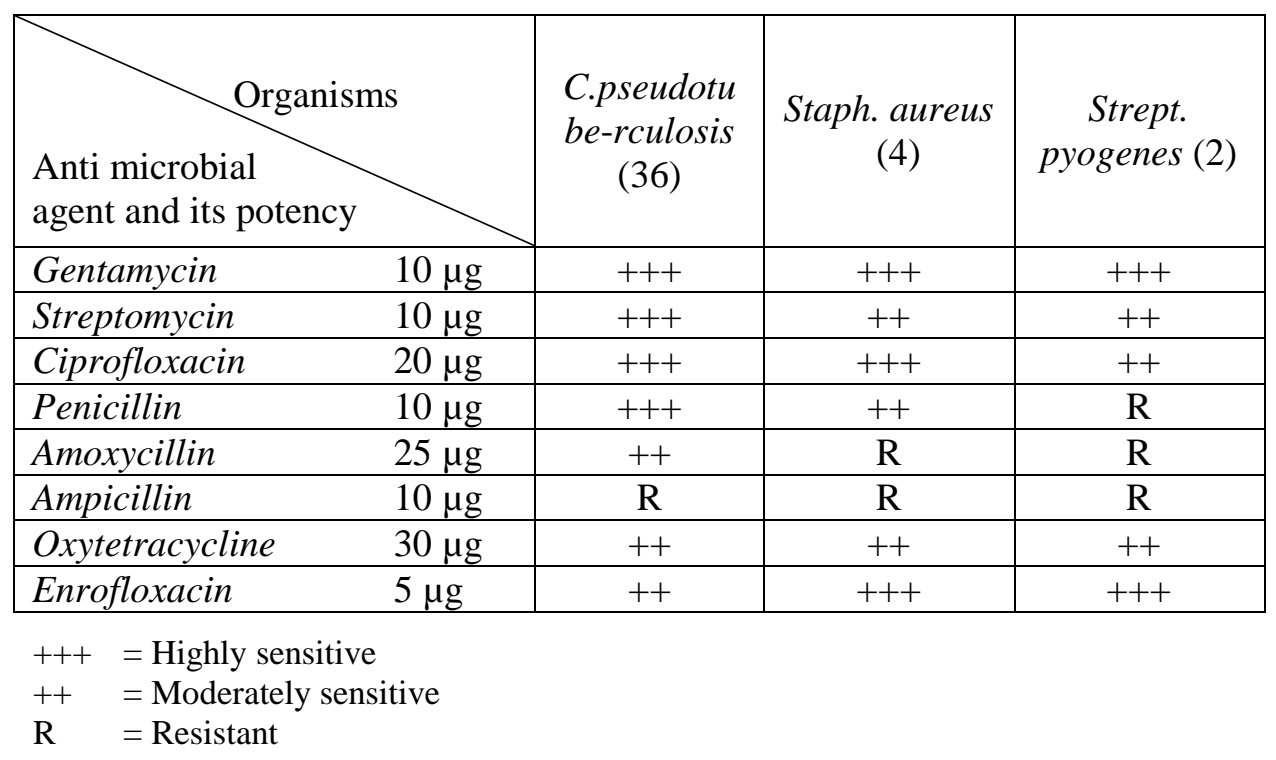




\section{DISCUSSION}

Oedematous skin disease (OSD) is an endemic infectious disease that appear mainly among buffaloes and occasionally cows in Egypt (Rafequ and Mahmoud, 2007).

The main cause of OSD in buffaloes is C. pseudotuberculosis which is a Gram-positive bacilli, small poleomorphic (straight to slightly curved), appears as short chain or clumps resembling Chinese letters, aerobic or facultative anaerobic, non motile, non spore forming and grow slowly on enriched media and produce a toxic phospholipase D (Blarksdale et al., 1981); Brown and Olander, 1987). The organism is capable of surviving within the phagocytes due to its high lipid content on the cell surface. (Tashjian and Campbell 1983; Pointkowski and Shivers 1998). Oedematous skin disease is an acute and seasonal disease appear often in summer and cause redness and swelling of skin in hairless areas, also cause sever economic losses through low quality of skin, decrease in meat production as well as long course of treatment (Ghoneim et al., 2001; Zaki, 2004; Syame, 2006).

Out of the examined 86 buffaloes 36 showed clinical signs of OSD (Closed and open lesions) representing a morbidity rate of $41.9 \%$ whereas no mortalities were recorded (Table 1 ). These results are relatively near to that mentioned by Zaghawa and El-Gharib (1996) who found that OSD in buffaloes were $44.3 \%$. Higher incidence of OSD was recorded by Sayed et al. (2007) who mentioned that morbidity of OSD was $95.5 \%$ between the buffaloes, while the lower incidence was recorded by Barakat et al. (1985); Abou-zaid (2001); Rafequ and Mahmoud (2007) with percent of $17.2 \%, 9.7 \%$ and $26.1 \%$ respectively.

Bacteriological results revealed that the isolation of C. pseudotuberculosis from closed lesions was 23(100\%) from 23positive cases and open lesions 7(53.8\%) from 13 positive cases. This results are nearly similar to those recorded by Sayed (2001) who isolated C.pseudotuberclosis from closed lesions in a higher rate than from open lesions with percent of $(86.6 \%)$ and $(58.3 \%)$ respectively. On the other hand El-Sayed (2006) isolated C.pseudotuberclosis (15\%) from closed lesions. C.pseudotuberclosis was isolated in pure culture $30(83.3 \%)$ from both closed and open lesions (Table 3). These results go hand to hand with those recorded by Khalil et al. (1995) who recorded that C.pseudotuberclosis was isolated from OSD infected animals with an incidence of (83.3\%). Zaghawa and El-Gharib (1996); Ali and Zaitoun (1999); Sayed (2001); Zaki (2004) and Sayed et al. (2007) detected C. pseudotuberculosis, in $88.2 \%, 94.5 \%, 77.5 \%, 12.8 \%$ and $80.0 \%$ of the 
OSD infected buffaloes, respectively.

In the present work $C$. pseudotuberculosis was isolated in mixed culture from open lesions only with Staphylococcus aureus 4 (30.8\%) and Streptoccus pyogenes 2 (15.4\%) (Table 3). On the other hand, Sayed (2001) isolated C. pseudotuberculosis, with Staphylococcus aureus (4 cases), anthracoid (3 cases), Streptococcus pyogenes (1 case) and E.coli (1 case). Mostafa (1984); Ali and Zaitoun (1999) and Sayed et al. (2007) found that mixed culture of C. pseudotuberculosis, with Staphylococcus spp. and Streptococcus spp. with percent of 10\%, with Staphylococcus spp. $15.3 \%$ and with streptococcus spp. $7.5 \%$ respectively. Biotyping of the isolated strains of C.pseudotuberculosis showed positive nitrate reduction test (Table 2). A result which come in accordance with that mentioned by Sayed (2001); Yeruham et al. (2003); Zaki (2004) and Abd El Ghafar (2009) recorded that the most of C.pseudotuberculosis which isolated from buffaloes were nitrate positive.

The variation in the disease frequency between the different studies may be attributed to the endemic nature of the disease which leads to variation in animal immunity and the variation in the presence of a few or large numbers of susceptible animals.

Concerning guinea pigs inoculation for studying both pathogenesis and re-isolation, all the inoculated isolates of C.pseudotuberculosis killed guinea pigs within $2-5$ days post injection (Table 4) where the dead guinea pigs showed congestion and maceration of muscles at site of injection in addition to congestion of the internal organs. This come in agreement with the findings of Barakat (1984); Khater et al. (1984); Galila (1998); El-Sawah (2002); Rafequ and Mahmoud (2007). Also Zaki (2004) reported that all isolates of C.pseudotuberclosis produced an exotoxin which was lethal for experimental animals usually within 48 hours of inoculation. The postmortem examination revealed congestion of internal organs. Table (5) revealed that the most isolates of C.pseudotuberculosis (main cause of OSD) were sensitive to Gentamycin, Penicillin, Ciprofloxacin and Streptomycin. Similar results were obtained by Hassan (1988) who said that combination of Penicillin with Sterptomycin showed good results in treatment of OSD. High sensitivity of Gentamycin was recorded by Khalil et al. (1995); Sayed (2001) and Sayed et al. (2007). On other hand, AbouZaid (2001) found that C.pseudotuberculosis strains were sensitive to Doxycycline, Erythromycin, Gentamycin and Cephalocin.

Finally, it could be concluded that, the oedematous skin disease in buffaloes is acute disease occurs in different localities in Egypt and mainly caused by C.pseudotuberculosis in single infection or in mixed infection with other bacteria. Therefore to prevent this disease it is recommended 
that hygienic measures must be taken in consideration in an area free from infected animals together with treatment with effective antibiotic as Gentamycin, Penicillin and Streptomycin in addition to control of insect vectors.

\section{REFERENCES}

Abd El Ghafar, E.A. (2009): Differentiation between exotoxin phospholipase-D of Corynebacterium pseudotuberculosis strains isolated from buffaloe and sheep. Ph.D. Thesis (Bacteriology), Faculty of Vet. Med., Kafr- Elshiekh University.

Abd El-Hakeim, M.I. (2005): Studies on oedematous skin disease in buffaloes at Gharbia Governorate. M.V.Sc., Thesis (Infectious Diseases), Faculty of Veterinary Medicine, Tanta University.

Abou-Zaid, A.A. (2001): Corynebacterium pseudotuberculosis in buffaloes goats and sheep. Vet. Med. J. Giza, Egypt, 49 (3): 432-450.

Al-Gaabary, M.H. and Ammar, K.M. (1999): Clinical and epidemiological studies on buffalo lymphangitis in Gharbia Governorate $5^{\text {th }}$ Sci. Cong., Assiut, Egypt, pp. 89-91.

Ali, H.S. and Zaitoun, A.M. (1999): Studies on cutaenous suppurative lymphangitis in buffaloes at Assiut Governorate, Egypt. Assiut. Vet. Med. J., 41 (81): 208-222.

Bailey and Scott's (1990): Diagnostic Microbiology $8^{\text {th }}$ edition. The C.V. Mosby Company. St. Louis.

Barakat, A.A.; Osman, E.A.; Afifi, E.A.; Gad, A.S. and Shouman, M.T. (1985): Occurrence of bovine oedematous skin disease in different province of Egypt. Vet. Med. Assoc., 44: 225-231.

Barakat, A.A.; Selim, S.A., Atef, A.; Saber, M.S.; Nafi, E.K. and El-Ebeedy, A.A. (1984): The serotypes of Corynebacterium pseudotuberculosis isolated from different animal species. Rev. Sci. Tech. Offic.Int. Epizootics, 3(1): 151-163.

Blarksdale, L.; Linder, R.; Sulea, I.T. and Pllice, M. (1981): Phospholipase

$\mathrm{D}$ activity of (Corynebacterium ovis) and C.ulcerans a distinctive maker within the genus Corynebacterium. J. Clin. Microbiol., 13 (2): 335-343.

Brown, C.C. and Olander, H.J. (1987): Caseous lymphadenitis of goats and sheep: A Review. Vet. Bull., 57 (1): 12.

EI-Far, F.A. (1976): Comparative bacteriological studies on C. ovis strains isolated from sheep, goats and bovine sources in Egypt. M.V.Sc. Thesis, (Bacteriology) Cairo, University. 
El-Sawah, A. (2002): Studies on Corynebacterium pseudotuberculosis infection in buffaloes. Ph.D. Thesis (Infectious Diseases) Cairo University.)

El-Sayed, M.Y.A. (2006): Comparative molecular characterization of Egypt isolates of Corynebacterium pseudotuberclosis: Special consideration to pulsed field gel electrophoresis patterns. Ph. D. Thesis (Microbiology), Faculty of Veterinary Medicine, Cairo University.

Fontaire, M.C. and Baird, G.J. (2008): Caseous lymphadenitis. Small Ruminant Research, 76 (1/2): 42-48.

Galila, M.I. (1998): Some studies on oedematous skin disease. M.V.Sc., Thesis, (Infectious diseases). Faculty of Veterinary Medicine, Zagazig, University.

Ghoneim, M.A.; Mousa, A.W.; Ibrahim, A.K.; Amin, A.S.; Khafagy, A. and Selim, S.A. (2001): Role of :Hippobosca equine as a transmitter of C. pseudotuberculosis among buffaloes by PCR and dot blot hybridization. .J. Egypt. Vet. Med. Assoc., 61 (3): 165-176.

Hassan, M.K.A. (1988): Studies on some infectious diseases causing oedema in buffaloes. M.V.Sc., Thesis (Infectious diseases), Faculty of Veterinary Medicine, Cairo University.

Ibrahim, A.K.; Seedy, F.R. and Hassan, W.H. (2007): The role of Corynbacterial phospholipase D vaccine in activation of macrophages. BS. Vet. Med. J. Vol. 17 No. 1, P. 50-55.

Khalil, N.G.; Seddek, S.R. and Nashed, S.M. (1995): Studies on ulcerative lymphangitis in buffaloes in Assiut. Assiut Vet. Med. J., 33 (65): 93-99.

Khater, A.R.; Bayoumi, A.N; EI-Deeb, S. and Salem, H. (1984): Studies on experimental infection of C. ovis. II. Comparative studies on the effect of 2 strains in sheep. Assiut. Vet. Med. J. 11 (21): 95-99.

Koneman, K.W.; Allen, S.D.; Dow ell, V.R. mid and Sommers, H.M. (1992): Colour Atlas and Textbook of Diagnostic Microbiology. $2^{\text {nd }}$ ed.; J.B. Lippicott Co., London.

Mostafa, M.E.M. (1984): Studies on the so called oedematous skin disease.

M.V.Sc., Thesis (Infectious disease), Faculty of Veterinary Medicine. Zagazig University.

Pandey, G.S.; Nambota, A.M.; Muliokela, L. and Mubita, D.H. (2007): Caseous lymphadenitis among boer goats in Batoka, Zambia. Indian Vet. J., 84 (5): 461-462.

Piontkowski, M.D. and Shivers, W. (1998): Evaluation of commercial available vaccine against Corynebacterium pseudotuberculosis. JAVMA., 212 (11): 1765-1768. 
Quinn, P.J.; Markey, B.K.; Carter, M.E.; Donelly, W.J.C. and Leonard, F.C. (2002): Veterinary Microbiology and Microbial Diseases, Iowa State University Press, Blackwell Science.

Rafequ, A.M. and Mahmoud, H.K (2007): Bacteriological studies on oedematous skin disease in Fayoum Governorate J. Egypt. Vet. Med. Assoc., 67 (3): 197-206.

Sayed, A.M. (2001): Corynebacterium pseudotuberculosis in cattle skin oedematous disease in Assiut Governorate. Assiut Vet. Med. J., 45 (90): 264-272.

Sayed, S.; Rateb, H.Z.; Arafa, M.I.; Abdel-Hafeez, M.M. and Amer, A.A. (2007): Field study on buffaloes oedematous skin disease in Assiut Governorate model study. Assiut Vet. Med. J., 53 (114): 189-206.

Selim, S.A. (2001): Review: Edematous: skin disease of buffaloes in Egypt. Vet. Med. J. B. 48: 241-258.

Syame, S.M.F. (2006): Preparation and evaluation of Corynebacterium pseudotuberculosis vaccine in buffalo. Ph.D. Thesis (Microbiology), Faculty of Veterinary Medicine, Cairo University.

Tashjian, J.J. and Campbell, S.G. (1983): Interaction between caprine macrophages and C.pseudotuberculosis: an electron microscope study. Am .J. Vet. Res., 44 (4): 690-693.

Yeruham, I.; Elad, D.; Friedman, S. and Perl, S. (2003): Corynebacterium pseudotuberculosis infection in Israeli dairy cattle. Epidemiol. Infect., 131 (2): 947-955.

Zaghawa, A.A. and El-Gharib, S.A. (1996): Outbreak of oedmatous skin disease in Alexandria during 1994: Clinical investigation and assessment of epidemiological parameters. $7^{\text {th }}$ Sci. Cong., 17-19 Nov. 1996, Faculty of Veterinary Medicine, Assiut University, Egypt, 617-616.

Zaki, E.R. (2004): Assessment of the role played by Corynebacterium pseudotuberculosis exotoxin in inducing oedematous skin disease in buffaloes. J. Egypt. Vet. Med. Assco., 64 (6): 171-181. 